\title{
Peningkatan Pengetahuan Masyarakat Kampung Padamulya Desa Padamulya Mengenai Ekonomi Syariah Melalui Program GRES (Gerakan Ekonomi Syariah)
}

\section{Increasing The Knowledge Of Padamulya Villagers About The Sharia Economy Through The GRES Program (Islamic Economic Movement)}

\author{
H. Ismail ${ }^{1}$ \\ 1Program Studi Ekonomi Syariah, Fakultas Ekonomi Islam, Universitas Djuanda Bogor Jl. \\ Tol Ciawi No. 1, Kotak Pos 35 Ciawi, Bogor 16720, e-mail: harisismail875@gmail.com
}

(Diterima: 25-06-2020; Ditelaah: 25-09-2020; Disetujui: 10-02-2021)

\begin{abstract}
Abstrak
Kegiatan Sosialisasi dilaksanakan di Desa Padamulya, dengan target masyarakat bapak-bapak dalam pengajian mingguan. Kegiatan sosialisasi dilaksanakan dengan tujuan memberikan pemahaman kepada masyarakat mengenai manfaat dan pentingnya ekonomi syariah yang dilakukan tidak hanya berorientasi pada profit semata, melainkan kegiatan perekonomian dapat terus berkembang di masa mendatang dengan memperhatikan dan menerapkan ekonomi syariah sebagai faktor pendukung. Sosialisasi tersebut disesuaikan dengan permasalahan dan kebutuhan yang dihadapi oleh masyarakat di Desa Padamulya. Metode pelaksaan kegiatan terdiri dari dua tahap. Pertama tahap persiapan materi dan perizinan dan tahap kedua yaitu tahap pelaksanaan program berupa sosialisasi meliputi pemaparan dan diskusi. Hasil dan luaran kegiatan setelah dilaksanakan sosialisasi yaitu pertama, masyarakat mengalami peningkatan pemahaman mengenai ilmu ekonomi syariah. Dengan dilaksanakannya program ini, maka terjadi perbaikan tatanan nilai masyarakat di bidang ekonomi khususnya ekonomi syariah.
\end{abstract}

Kata kunci: Ekonomi Syariah, Kegiatan, Masyarakat, Metode, Sosialisasi.

\begin{abstract}
The socialization activity was carried out in Padamulya Village, with the target community being gentlemen in weekly recitations. The socialization activities are carried out with the aim of providing an understanding to the public regarding the benefits and importance of Islamic economics which are carried out not only oriented to profit alone, but economic activities can continue to develop in the future by paying attention to and implementing Islamic economics as a supporting factor. The socialization was adapted to the problems and needs faced by the community in Padamulya Village. The activity implementation method consists of two stages. The first stage is the preparation of materials and permits and the second stage is the program implementation stage in the form of socialization including exposure and discussion. The results and outputs of the activities after the socialization were carried out were, first, the community experienced an increase in understanding of sharia economics. With the implementation of this program, there will be an improvement in the order of community values in the economic field, especially sharia economics.
\end{abstract}

Keywords: Activities, Methods, Sharia Economy, Socialization, Society.

\section{PENDAHULUAN}

Islam merupakan sebuah agama yang memperhatikan segala hal dari manfaat dan dari setiap hubungan ummatnya baik dalam hubungan secara vertikal maupun horizontal. Begitu juga dalam hal hadirnya ekonomi syariah, islam sangat serius mengatur urusan tersebut sesuai dengan ketentuan agama agar tercipta kemaslahatan 
Ismail

Peningkatan Pengetahuan Masyarakat Kampung Padamulya Desa Padamulya Mengenai Ekonomi Syariah Melalui Program GRES (Gerakan Ekonomi Syariah)

ummat manusia serta menjauhkan ummat manusia dari hal yang dilarang agama yakni adanya riba dalam kegiatan ekonomi. Adanya masyarakat yang belum mengetahui ketentuan-ketentuan dalam ekonomi Syariah dan apa saja manfaat dari ekonomi Syariah, perlu dengan dilakukannya sosialisasi, pemaparan dan pengenalan terkait ekonomi syariah dan Strategi yang pada sosialisasi akan dapat membantu masyarakat dalam kehidupan sehari-hari dan untuk mengembangkan perekonomian. Masyarakat akan dapat memahami lebih dalam jika strategi sosialisasi ditujukan khusus kepada kehidupan sehari-hari, karena pada umumnya kegiatan ekonomi dilakukan setiap hari oleh masyarakat. Begitupun manfaat akan lebih terasa langsung oleh masyarakat jika dipraktikan langsung dibandingkan hanya teori yang tidak dikhususkan pada suatu sasaran. Sosialisasi kepada masyarakat yang dilaksanakan pada masyarakat di Desa Padamulya sebagai target program dengan tujuan agar masyarakat mendapatkan pemahaman mengenai manfaat dan pentingnya ekonomi syariah sehingga pemahaman tersebut dapat diterapkan dalam kegiatan perekonomian serta dapat memperbaiki kegiatan usaha yang sedang dijalankan dan diharapkan dapat lebih mengerti dan dapat mempraktikkan langsung. Dengan begitu, masyarakat Desa Padamulya dapat menjalankan kegiatan perekonomian sesuai dengan syariah.

\section{METODE PELAKSANAAN}

Pelaksanaan kegiatan dimulai dengan persiapan mencari materi yang akan dibahas lalu survey awal untuk melihat kondisi kesiapan responden di lapangan dan sosialisasi. Responden dalam kegiatan ini terdiri dari bapak-bapak dan pemuda-pemuda di Desa Padamulya, seluruh yang hadir dalam kegiatan sosialisasi berjumlah 40 orang. Pelaksanaan kegiatan ini menggunakan metode ceramah.

\section{HASIL \& PEMBAHASAN}

Kegiatan sosialisasi ini di hadiri oleh 40 orang, Pelaksanaannya yaitu di Nurul Iman Desa Padamulya. Materi yang disampaikan pada kegiatan sosialisasi ini adalah tentang Pengenalan, fungsi serta manfaat mengenai LKMS dan juga membahas tentang riba, yang mana LKMS merupaka solusi dari terjadinya praktik riba di masyarakat tujuan dilaksanakannya sosialisasi mengenai LKMS ini yaitu agar masyarakat mengetahui apa itu LKMS dan juga riba, karna hal ini sangat penting dalam kegiatan perekonomian. Setelah pemaparan dilakukan diskusi agar masyarakat dapat memahami materi yang dibahas dengan mengajukan pertanyaan dan sharing mengenai yang dibahas dan masyarakat antusias menyampaikan berbagai pertanyaan.

\section{Pelaksanaan Kegiatan}

Sosialisasi bertema "Manfaat Ekonomi Syariah" yang dilaksanakan pada Hari Jum'at tanggal 16 Agustus 2019 yang bertempat di masjid Daarussalam dusun Lingkungsari pada pukul 13.00 sampai 15.00 WIB. Dalam persiapan sosialisasi ini dila 
Ismail

Peningkatan Pengetahuan Masyarakat Kampung Padamulya Desa Padamulya Mengenai Ekonomi Syariah Melalui Program GRES (Gerakan Ekonomi Syariah)

sebelum pelaksanaan, kegiatan sosialisasi dalam tahap pelaksanaan kegiatan sosialisasi program sosialisasi ini dilaksanakan 1 (satu) kali di Masjid Darussalam. Dan dalam kegiatan sosialisasi Ekonomi Syariah ini yang membahas tentang Manfaat yang ada dalam Ekonomi Syariah ini Sosialisasi yang dilakukan berbentuk ceramah atau pemaparan kemudian setelah pemaparan, dilakukan diskusi dan tanya jawab agar dapat mengetahui sejauh mana masyarakat mengerti dari pemaparan yang telah disampaikan. Dan materi yang disampaikan dalam kegiatan sosialisasi Ekonomi Syariah ini yaitu membahas tentang Manfaat yang ada dalam Ekonomi Syariah Dan Dasar-dasar dalam ekonomi syariah kemudian Bagaimana perilaku masyarakat dalam melakukan kegiatan perekonomian yang sesuai ekonomi syariah dalam kehidupan sehari-hari dan membahas Berbagai pemanfaatan Sumber daya alam yang ada disekitar kita yang pemanfaatannya sesuai dengan syariah. Dalam materi-materi diatas berdampak positif dengan melihat respon baik dari masyarakat yang hadir dalam sosialisasi dan juga materi diatas berdampak positif terhadap keadaan perekonomian mereka contohnya seperti memanfaatkan sumber daya alam secara baik dan tidak ada kecurangan dalam pemanfaatan Sumber daya alam tersebut dan harus mengikuti sesuai dengan ajaran syariah. Dan juga dengan adanya pemaparan materi dalam kegiatan sosialisasi ini diharapkan menyadari bahwa kegiatan yang dilakukan sehari-hari harus sesuai dengan kiat-kiat yang ada di dalam syariah.

Indikator Hasil dan Manfaat

Hasil dan manfaat dari pelatihan ini antara lain para masyarakat sudah memiliki peningkatan pengetahuan tentang ekonomi syariah. Setelah mendapat pemaparan melalui metode ceramah, berdasarkan hasil monitoring dan evaluasi peserta telah mengetahui tentang ekonomi syariah.

\section{KESIMPULAN}

Pelaksanaan kegiatan sosialisasi ini menunjukan bahwa adanya peningkatan kesadaran serta minat dari masyarakat untuk menerapkan ekonomi syariah dalam mengembangkan sistem ekonomi syariah sehingga dapat meningkatkan perekonomian bagi masyarakat di Desa Padamulya. Kemudian masyarakat yang ikut serta dalam kegiatan sosialisasi berlangsung memberikan respon yang sangat baik dari segi perizinan tempat, pemaparan, sharing, dan pada saat diskusi. Masyarakat sangat antusias dalam mengikuti kegiatan sosialisasi ini terlihat dari minat masyarakat untuk menerapkan sistem yang ada dalam ekonomi syariah setelah mengetahui banyak manfaat yang ada dalam ekonomi syariah dan pengetahuan masyarakat meningkat terutama tentang materi yang berkaitan dengan ekonomi syariah yaitu LKMS.

\section{DAFTAR PUSTAKA}

Anshori, M. Y. (2018). Laporan Individu Kegiatan Kuliah Kerja Nyata di Desa Cimanggu Kec. Kabandungan Kab. Sukabumi. 
Ismail

Peningkatan Pengetahuan Masyarakat Kampung Padamulya Desa Padamulya Mengenai

Ekonomi Syariah Melalui Program GRES (Gerakan Ekonomi Syariah)

Buku Panduan Kuliah Kerja Nyata Fakultas Ekonomi Islam Universitas Djuanda Bogor 2019

Dewi,S.H.,M, N. (2017, Februari - Juli). Regulasi Keberadaan BMT dalam Sistem Perekonomian di Indonesia. Jurnal Serambi Hukum, Vol. 11 No. 1, Pp. 96-97

Gayo, A. A,. \& Taufik, I. A. (2012, Agustus). Kedudukan Fatwa DSN-MUI dalam Mendorong Perkembangan Bisnis perbankan Syariah (Perspektif Hukum Perbankan Syariah). Jurnal Rechtvinding (Media Pembinaan Hukum Nasional), Vol. 1 No. 2, Pp. 262

Jenita. (2017, Desember). Peran Lembaga Keuangan Mikro syariah dalam Pemberdayaan Ekonomi Masyarakat Kecil Menengah. Jurnal Lembaga Keuangan dan Perbankan, Vol. 2. No. 2, Pp. 3Hidayah, A. N., \& Kartini, I. A. (2016). Peran Bank dalam Sosialisasi dan Edukasi Jasa Perbankan Syariah. Jurnal Kosmik Hukum, Vol. 16 No. 1, Pp. 75

Khadijah S, Saleh NEP, Kamarudin MF, Haryadi A. 2013. Sustainability of Islamic Micro Finance Institution (IMFIs). Journal Of Accounting and Finance. DOI. 10.13189/ujaf.2013.010205

Kusmanto, Y. T. (2014). Pengembangan Ekonomi Islam Berbasis Kependudukan di Perdesaan. Jurnal Ilmu Dakwah, Vol. 34 No. 2, Pp. 232

Lasmiatun. (2017). Peran dan Kebijakan Pemerintah melalui LKM/LKMS untuk Menciptakan Kesejahteraan dan Keadilan Distributif. Jurnal Dimensi, Vol. 10 No. 2, Pp. 41

Octaviani , V., Narti , S., \& Nurwita, S. (2018). Peningkatan Sumber Daya Masyarakat Desa dalam BinaanPusat Kegiatan Belajar Masyarakat (PKBM). Jurnal Pengabdian Pada Masyarakat. 